\title{
The first evidence of predatory or parasitic drilling in stylophoran echinoderms
}

\author{
Bradley Deline \\ Acta Palaeontologica Polonica 53 (4), 2008: 739-743 doi:http://dx.doi.org/10.4202/app.2008.0416
}

Drillholes are common in many different echinoderm classes, but have yet to be reported in homalozoans. A borehole in the Late Ordovician echinoderm Enoploura is the first evidence of drilling in Stylophora. The level of preservation and environmental setting suggest this drilling occurred while the organism was alive, thus supporting a predatory or parasitic interpretation.

Bradley Deline [delinebl@email.uc.edu], Department of Geology, University of Cincinnati, Cincinnati, Ohio 45221, USA.

This is an open-access article distributed under the terms of the Creative Commons Attribution License (for details please see creativecommons.org), which permits unrestricted use, distribution, and reproduction in any medium, provided the original author and source are credited.

ForF Full text (424.8 kB) 